\title{
TIŠTĚNÁ MÉDIA PRO KATOLICKOU MLÁDEŽ PRIZMATEM TEOLINGVISTIKY'
}

\section{IRENA BOGOCZOVÁ, ZUZANA ČERNÁ}

\section{PRINTED MEDIA FOR THE CATHOLIC YOUTH THROUGHT THE PRISM OF THEOLINGUISTICS}

ABSTRACT The article treats the language of selected magazines for (not only) Catholic children and young readers. First, it explains the term theolinguistics, its early days and development. Then, it analyzes authentic materials from three journals - Tarsicius, In! and Nezbeda. The authors survey mainly the lexical level, formulating the main findings and illustrating them with numerous examples.

KEY WORDS Sacrum, language, Catholic journals, children, youth

CONTACT Filozofická fakulta Ostravské univerzity; irena.bogoczova@osu.cz, A18602@student.osu.cz

1 Příspěvek vznikl v rámci řešení projektu Studentské grantové soutěže Ostravské univerzity, přesněji na katedře slavistiky její Filozofické fakulty (SGSO4/FF/2019-2020), nazvaného Obraz sacrum v jazyce křest'anské mládeže, SGSO4/FF/2019-2020. 


\section{1 / UVEDENÍ DO PROBLEMATIKY}

Teolingvistika je relativně mladá jazykovědná disciplína, i když ne natolik mladá, aby vzhledem $\mathrm{k}$ uplynulým třem až čtyřem dekádám bádání neměla širší vědecké veřejnosti co nabídnout. Je pravda, že v českém prostředí není tolik známá jako např. v zemích, v nichž má církev silnější pozici, popř. je součástí či dokonce základem národní identity, ${ }^{2}$ a mnohá privilegia tam měla i v dobách totalitního, komunistického režimu. Pro postavení církve u nás mělo za uplynulých přibližně sto let rozhodující vliv několik faktorů. Především to bylo vcelku antiklerikální smýšlení politické reprezentace tzv. první československé republiky, další oslabení církve přinesly pochopitelně změny nastalé po roce 1948. To vše, včetně do jisté míry zmytologizovaného obrazu češství týkajícího se vzdálenější minulosti (česká gotika, období husitství, reformace, doba temna, protihabsburské národní obrození), prezentovaného krásnou literaturou, divadelní, filmovou a jinou uměleckou tvorbou či školní výukou, se celkově promítlo do obrazu církve v Čes$\mathrm{ku}$ (Československu), o čemž podrobně informují práce sociologů a historiků náboženství (srov. např. Václavík 2010, Hošek 2012, 2018). Smyslem předkládané studie je však něco jiného. Je to snaha seznámit přijemce s těžištěm zájmu zmíněné teolingvistiky, provést sondu do „náboženského jazyka" konkrétních psaných textů určených křestanské mládeži a poukázat na specifika vyjadřování, která jsme v nich zaznamenaly.

Není na tomto místě možné podat ucelený přehled výsledků výzkumné činnosti domácích a zahraničních teolingvistů a ani se o to nebudeme pokoušet, tím spíše, že věda již disponuje obsáhlými a fundovanějšími pracemi na toto téma. Jen na slovanské půdě vznikly nарг̌. Хрестоматия теолингвистики / Chrestomatia teolingwistyki (Łapicz, Gadomskij 2008), Хрестоматия теолингвистики 2 (Gadomskij, Chlebda, Čevela et al. 2019), monografie Теолингвистические исследования в славянском языкознании (Gadomskij 2017), několik studijních textů, např. Язык и религия (Mečkovskaja 1998), nebo sborníky příspěvků různých autorů: Теолингвистика (Gadomski, Končarević 2012), Теолингвистичка проучаваньа словенских језика (Končarević, Grković-Major 2013) aj. ${ }^{3}$

Mimořádné pozornosti se teolingvistice dostává v Polsku. Tam dokonce v rámci Výboru polského jazyka Polské akademie věd vznikla Komise náboženského jazyka (Komisja Języka Religijnego Rady Jezzyka Polskiego w Krakowie) a stejná komise působí také v rámci Mezinárodního komitétu slavistů. Nemalou tradicí se může pochlubit vydavatelská řada Teolingwistyka nakladatelství Biblos v Tarnově. ${ }^{4}$ Od r. 2004 se konají pravidelné teolingvistické konference v Poznani,

2 Toto zjištění platí nap̌r. pro Polsko, Srbsko a (nověji) Ukrajinu.

3 Slavista Александр Казимирович Гадомский (Aleksander Gadomski) působil dřive v Simferopolu, nyní - v Polsku; Нина Борисовна Мечковская stejně jako Валентина Авраамовна Маслова zastupují běloruskou jazykovědu; Ольга Александровна Прохватилова obhájila snad první ruskojazyčnou disertační práci v oboru teolingvistika, a to koncem 20 stol. ve Volgogradu (Končarević 2015, s. 58). Uved'me i další známá jména ruských (teo)lingvistů, k nimž patří: Валерий Петрович Даниленко, Леонид Петрович Крысин nebo Ирина Владимировна Бугаева. V Srbsku kromě uvedených badatelek, Ksenije Končarevićové působící na Pravoslavné bohoslovecké fakultě Univerzity v Bělehradě a Jasminy Grkovićové-Majorové spojené s novosadskou univerzitou, se teolingvistice věnují ještě např. Ružica Bajićová nebo Predrag Piper.

$4 \quad$ V tomto nakladatelství vyšlo do $\mathrm{r}$. 202014 samostatných titulů včetně jedné dvousvazkové práce. Přesnějšś informace o publikacích a veškeré bibliografické údaje jsou dostupné na https://biblos.pl/129-teolingwistyka 
z nichž vzešlo zatím 5 obsáhlých polskojazyčných sborníků př́ispěvků nazvaných Język religijny dawniej i dziś (2004, 2005, 2007, 2009-2x). ${ }^{5}$

K zástupcům polské teolingvistiky (ale také stylistiky, bez této užší specifikace) patřili/ patří tito jazykovědci a teologové: (v abecedním řazení) Irena Bajerowa, Marta Dalgiewicz, Andrzej Draguła, Stanisław Dziekoński, Aleksander Gadomski, Renata Grzegorczykowa, Maria Karpluk, Stanisław Koziara, Elżbieta Kucharska-Dreiß, Marzena Makuchowska, Bożena Matuszczyk, Alfons Nossol, Małgorzata Danuta Nowak, Renata Przybylska, Wiesław Przyczyna, Jadwiga Puzynina, Jadwiga Sambor, Agnieszka Sieradzka-Mruk, Jolanta Szarlej, Elżbieta Umińska-Tytoń, Maria Wojtak, Dorota Zdunkiewicz-Jedynak aj. ${ }^{6}$ V České republice se této problematice věnovali nebo věnují: Josef Bartoň, Naděžda Bayerová, Marcela Grygerková, Karel Komárek, Naděžda Kvítková, Eva Minářová, Michaela Laštovičková; na Slovensku: Jozef Mistrík nebo Jozef Mlacek. Za všechny práce jmenujme alespoň dvě monografie vzniklé na pưdě Ostravské univerzity: (ed.) Grygerková M., 2005, Specifika církevní komunikace. Ostrava: OU; Grygerková M., 2006, Slang v církevním prostředí. Ostrava: OU.7

$\mathrm{Z}$ těchto i dalších pramenů odvozujeme mj. vymezení termínu teolingvistika (popř. kritická teolingvistika, ${ }^{8}$ obecná a aplikovaná teolingvistikaํ), kterým se chápe pomezní disciplínu na rozhraní teologie a jazykovědy (starší pojetí) nebo jako etablovanou lingvistickou subdisciplínu patřící do tzv. vnější jazykovědy, jež má nejblíže k teorii komunikace, kulturní antropologii a sémiotice. Nejde tedy pouze o hermeneutický vědní obor zkoumající biblické texty, popř. (meta)jazyk biblistů, religionistů, teologů či katechetů, ale o směr bádání, který reflektuje jazykové chování zpơsobené alespoň předpokládanou existencí Boha (zahrnuje komunikaci s Ním a na Jeho téma), jakož i jazykové chování podmíněné potřebou jednotlivce fungovat v komunitě věřících, v celé složité struktuře církve (Kucharska-Dreiß 2004: 26). Teolingvistika se dále zaměřuje na práci s autentickým jazykovým materiálem, analýzu a deskripci jednotlivých

5 Stejnojmenná konference se koná cyklicky nadále, materiály jsou publikovány spíše v různých jiných vědeckých periodikách - v polštině, anebo komplexně - v angličtině.

6 Souběžně s teoretickým bádáním se objevují i nové formy evangelizace. Bezpočet takových projektů vzniká na internetu. Známý je např̀. ilustrovaný překlad Janova evangelia Dobra czytanka wg św. zioma Janka; srovnatelná - co se týče jazyka a způsobu narace - s Flekovou Parabiblí. Ve Varšavě se od r. 2008 pořádá festival křestanského hip hopu a v letech 2004 a 2009 proběhl tamtéž festival Święte Elo; primárně mladým lidem je určena akce Przystanek Jezus atd.

7 Literární produkce $\mathrm{v}$ českém prostředí se zaměřuje hlavně na tři oblasti: (1) sociologie náboženství (srov. nap̌r. P. Ambros, D. Červenková, D. Hamplová, J. Hanuš, P. Hošek, P. Fiala, D. Lužný, M. Martinek, Z. R, Nešpor, J. Pejřimovský, P. Říčan, I. O. Štampach, O. Štěch, D. Václavík, R. Vido), vč. překladů děl zahraničních autorů (U. Beck, P. L. Berger, J. Bocheński, M. Eliade, G. Greene, F. Hadjadj, K. Frielingsdorf, G. Lipovetsky, D. Lyon, R. Otto, Ch. Taylor aj.), a (2) na žánr, který lze označit jako duchovní interview (J. Jandourek - T. Halík, T. Halík - A. Grün, M. Veselovský - T. Holub, M. Ližičiar - J. M. Kašparů, J. Valenta - M. O. Vácha, M. Zahradníková - Z. Czendlik apod.), či (3) duchovní monolog, duchovní esej (J. M. Kašparů, M. O. Vácha, P. Dvořáková atd.). Ve druhém případech se o věcech víry, křestanské morálky či života církve (duchovenstva) pojednává populární, odlehčenou formou.

8 Badatele zajímá nejen samotný jazyk, ale i to, zda není zneužíván pro jisté estetické, komerční nebo ideologické účely.

9 Teolingvistika může být chápána obecně (v širším slova smyslu), nebo jako dílčí (aplikovaná) teolingvistika. Ta „obecná“, teoretická, pátrá po univerzálních otázkách, tématech a žánrech náboženského stylu (viz dále), zatímco druhá vychází z předpokladu, že náboženský jazyk má v různých církvích (konfesích) jistá specifika spojená s odlišnými výklady víry. 
žánrů verbalizované duchovní zkušenosti. Může se dotýkat otázek překladu náboženských textů, stanovení normy náboženského jazyka, tvorby kánonu sakrálních jazykových projevů, systematizace jejich variet a funkcí apod. Není bez zajímavosti, že se teolingvistice, zejména v zemích bývalého východního bloku, věnovali lingvisté s osobním vztahem k transcendentnu, osoby věřící, znalé náboženských textů a církevní komunikace. Dále nutno zdůraznit, že dříve než se termín teolingvistika dostal do povědomí odborníků, řada předních jazykovědců se již dlouhodobě věnovala např. stylu náboženských textů, církevnímu diskurzu a dílčím otázkám souvisejícím s duchovním životem člověka, byt své práce neoznačovala nějakými vyhraněnými termíny, ale považovala je jednoduše za stylistické nebo sociolingvistické.

Jak jsme již naznačily, důležité místo v rámci teolingvistiky zaujímají analýzy konkrétních náboženských textů. Nejdříve se badatelé pokusili tyto texty nějakým způsobem utřídit, vyčlenit a pojmenovat jejich kategorie (žánry), k čemuž docházelo již v 70. letech 20. stol. (např. Poláci Jan Kanty Wierusz-Kowalski, později Irena Bajerowa, Maria Karpluk, Jadwiga Sambor, slovenský jazykovědec Jozef Mistrík). Souběžně s tím vznikala postupně teorie oboru a utvářela se jeho metodologie. Badatelé se shodují v tom, že množina dílčích útvarů náboženského stylu je otevřená a s nástupem nových technologií jich neustále přibývá. Zjištují, že existují jisté typické, centrální žánry duchovních textů (např. samotný křestanský prototext - Bible) vedle těch okrajových, smíšených, stylově nevymezených. Mohou to být teologické spisy, texty sloužící k výuce náboženství, tzv. svědectví víry neboli lidová zbožnost, modlitby, písně/hymny, různé církevní dokumenty, originální umělecká tvorba, tištěná publicistika, hypertexty komunikace probíhající v kyberprostoru, které nejsou určeny k lineálnímu čtení a díky četným odkazům na další stránky čtenář sám rozhoduje o rozsahu a podobě (grafické, zvukové, obrazové) sdělení, kterému věnuje pozornost.

Dlužno dodat, že kromě názvu teolingvistika se můžeme v přislušné literatuře setkat i se starším anglickým označením theography, které v 60. letech 20. stol. navrhl anglikánský kněz Johan A. T. Robinson. Dnes používaný termín theolinguistics použil Belgičan Jean-Pierre van Noppen (poprvé ve své disertační práci zveřejněné v r. 1976, revidované 1981) a zpopularizoval jej britský jazykovědec David Crystal tím, že teolingvistiku jako encyklopedické heslo začlenil do prestižní The Cambridge Encyklopedia of Language (1987). ${ }^{10}$ Německý teolog a akademický pracovník Andreas Wagner ve svém článku z r. 1999 nazvaném výmluvně Theolinguistik? - Theolinguistik! ${ }^{11}$ dále rozpracoval termín teolingvistika, vymezil jej vưči socio- a neurolingvistice a nastínil, co by asi mělo být jejím úkolem.

10 Novější Crystalova definice tohoto oboru odpovídá v podstatě tomu, co bylo zmíněno výše. Podle autora je teolingvistika termín užívaný pro studium vztahu mezi jazykem a náboženským myšlením, jazykem a náboženskou praxí, která využívá obřadné texty a různé teolingvistické žánry jako např. kázání, sdělování/šíření církevních dogmat, soukromá svědectví víry aj. (Crystal 2008).

11 In: Spillmann, H. O., Warnke, I. (eds.), 1999, Internationale Tendenzen der Syntaktik, Semantik und Pragmatik (Akten des 32. Linguistischen Kolloquiums in Kassel 1997). „Linguistik International“, I (pp. 507-512). Frankfurt am Main: Peter Lang, 1999. 
Předmětem zájmu teolingvistiky je lingua sacra, ${ }^{12}$ neboli jazyk používaný ve sféře sacrum ${ }^{13}$ a ve vztahu k ní, jinak řečeno náboženský jazyk. Moderní pojetí sacrum ve významu používaném v odborné literatuře má kořeny ve známé, byt poměrně útlé práci německého filozofa Rudolfa Otta Das Heilige z r. 1917, ${ }^{14}$ na nějž v devadesátých letech navázal např. polský katolický kněz Alfons Nossol.

Dřív než se náboženskému jazyku začneme věnovat podrobněji (viz 2. část článku), rády bychom nejdřive odpověděly na otázku, zda je vưbec opodstatněné mluvit o nějakém specifickém sakrálním kódu. Wiesław Przyczyna svého času odlišil „jazyk Boha“ od „jazyka člověka“. Jazyk ve smyslu hebrejského pojmu „dabar“, který údajně znamená slovo, které „se stává“, proměňuje vyř̌čné ve skutečnost, patří do oblasti teologie. Jazykověda se, jak známo, soustředí bud' na jazyk ve významu systému prostředků, anebo na realizaci jazyka, tedy mluvu, mluvení. Jazyk-logos, jak jej známe z antické řecké kultury, představuje reálné sdělení, předání jisté myšlenky někomu jinému za účelem, aby poznal její obsah a pochopil jej (Przyczyna 1994: 167, 168), a to i v př́padě, že se týká něčeho nadpřirozeného.

Pro účely této studie je vymezení předmětu našeho výzkumu, tedy jazyka sacrum, stěžejní. Většina badatelů, z jejichž prací jsme při př́pravě tohoto článku vycházely, se shoduje v tom, že žádný předem daný sakrální kód neexistuje, ale že to, co odlišuje náboženské jazykové projevy od nenáboženských, plyne z jejich odlišných funkcí, z určitého situačního kontextu. Existuje-li tedy určitý druh náboženské realizace jazyka, je možné stanovit její základní rysy. Mezi ně patř́i podle většiny autorů na jedné straně archaičnost (tradicionálnost), ${ }^{15}$ rituálnost, symboličnost, umělost (formálnost), knižnost, uměleckost, správnost (korektnost), majestátnost, patetičnost či oslavnost, na druhé - expresivita, intimita, upř́mnost, dialogičnost, kontaktnost aj. ${ }^{16}$

Stejně jak jsme se ptaly po jedinečnosti fenoménu lingua sacra obecně, ptáme se nyní po svébytnosti lingua sacra iuvenum. Používají mladí věřící skutečně jiný jazyk než jejich (pra)rodiče? Mění se $\mathrm{v}$ poslední době nějakým podstatným způsobem přímo jazyk jejich vyjadřování o Bohu a k Bohu? Pakliže ano, projevuje se to i na stránkách křestanských dětských časopisů? Badatelé skutečně takovouto změnu zaznamenávají a zaujímají k ní odlišné postoje. Působí zde nepochybně jazyk profánní popkultury, jazyk ulice obsahující nespisovné prostředky

12 Dále se ve slovanské literatuře více či méně ujaly pojmenování: sakrální jazyk, religiózní jazyk, duchovní jazyk, náboženský jazyk, jazyk víry, religiolekt, náboženský idiolekt (sociolekt), církevní slang, jazyk náboženských projevi̊ apod.

13 Slovo sacrum chápeme ve shodě s př́slušnou odbornou literaturou jako synonymní k pojmům transcendence/transcendentnost, numinosum/numinosno/numinosnost, mystérium, spiritualita, tajemno, posvátno, duchovno atd. a v tomto významu jej v článku používáme. Sacrum je umožněno lidskou schopností duchovního prožitku (mysterium tremendum), který vyvolává úžas (fascinaci) a zároveň úctu ke svátosti.

14 Přeloženo do češtiny Janem Škodou jako Posvátno. Iracionalita $v$ ideji božství a jeji poměr $k$ racionalitě (Praha: Vyšehrad, 1998).

15 Náboženskému jazyku se často vytýká hlavně jeho nesrozumitelnost, což je logické, uvědomíme-li si, že biblické texty vznikaly před dvěma tisíci let ve zcela odlišných životních, geografických a klimatických podmínkách, jsou zasazeny do jiných společenských poměrů i krajiny, do kultury založené na zemědělství a kmenové (patriarchální) př̌slušnosti. Za odtažitost náboženského jazyka může, jak tvrdí polská teolingvistika, i přerušení kontinua předávání náboženských obsahů (Zdunkiewicz-Jedynak 2010: 89), což pro českou společnost platí dvojnásobně.

16 V některých typech církevní komunikace navíc hraje významnou roli i nejazyková složka (intersémiotické prvky): hudba, oděv, gesta, hmotné rekvizity. 
(vč. vulgarismů), anglicismy, výrazy slangové aj., což poskytuje prostor pro jazykovou kreativitu. Také evangelium, „velký př́běh“ lze sdělovat atraktivně, s lehkostí, mnohdy zábavně. Čerpá se přitom z jazyka politiky, žurnalistiky (zpravodajství), reklamy, z běžně mluveného jazyka. Tento profánní zpơsob vyjadřování náboženských obsahů je zastáván i kritizován samotnými věřícími - laiky i teology. Pozitivně i negativně na něj reagují jazykovědci i tvůrci různých evangelizačních a vzdělávacích pořadů, členové církve pracující s mládeží apod. V odborné diskusi na toto téma se někdy mluví přímo o posedlosti snahou "polidštit“ a aktualizovat náboženský jazyk (inkulturační obsese) a nový způsob komunikace je přijímán s rozpaky: na jedné straně jsme ještě zcela neopustili tradiční jazyk, vưči kterému máme spoustu výhrad, na druhé straně jsme si zatím nezvykli na jazyk, po kterém voláme. ${ }^{17} \mathrm{Z}$ předchozích sond ${ }^{18}$ do náboženského hip hopu či z rozboru jazyka Parabible Alexandra Fleka $(2018,2019)$ však plyne, že tyto novoty nejsou věříími předem odmítány. Popularita takovýchto textů svědčí o tom, že je po nich poptávka. ${ }^{19}$ Dokonce samotní kněží připouštějí, že informace sdělované běžně mluveným jazykem umožňují hlubší prožitek Božího slova a že „popová“ stylizace nemusí nutně Boha profanovat, jak se to snaží dokázat např. zmíněná Zdunkiewicz-Jedynak (2004). Naopak, bibličtí hrdinové jsou více podobní současným lidem, kteří jsou schopni lépe pochopit motivaci jejich chování. Autoři náboženských textů zatím lavírují mezi jazykem atraktivnějším, srozumitelnější a rizikem zploštění spirituálních obsahů, znepřátelení si části komunity věřících.

I z výše uvedených důvodů je nesnadné, snad nemožné stanovit normu jazyka sacrum, stejně jako definovat náboženský styl, ${ }^{20}$ který je polymorfní a má př̀esahy do jiných stylových oblastí. Podobně uvažuje slovenský jazykovědec Josef Mlacek (2012), když hledá odpověd' na otázku, proč se již dříve (např. v době první republiky, kdy teorie funkčních stylu byla v centru zájmu české/československé lingvistiky) náboženský styl vůči ostatním stylům vůbec nevymezil. Ve Stylistice současné češtiny narazíme na „duchovní řeč“ vyčleněnou z množiny žánrů řečnického stylu (Krčmová 1997: 208), které je věnován jeden odstavec výkladu. V něm se zmiňuje kázání, homilie a prŕležitostné řeči a konstatuje, že „[v] minulosti byly tyto řeči reprezentantem mluvené podoby vysokého stylu spisovného jazyka, v současnosti však v nich vyrůstá komunikativnost a tradiční modely ustupují stylizované bezprostřednosti ve vyjadřování“. O oprávněnosti vydělovat náboženský styl většina pramenů pochybuje, i když Marzena Makuchowska v r. 1995 správně předpovídala, že si brzy získá pozornost badatelů (1995: 449). ${ }^{21}$ Jako opodstatněný se zdá pojem biblický styl, jistá specifika má také kazatelství (Mlacek, Mistrík, Zdunkiewicz-Jedynak, Wojtak aj.).

17 Ostatně od druhého vatikánského koncilu (1962-1965) je snahou církve uvedení náboženství do souladu s dneškem, moderním světem, každodenní realitou věřících (srov. tzv. aggiornamento).

18 Do tisku byly odevzdány studie členek projektového týmu: Bogoczová I., Parszewská A. Parabiblia Alexandra Fleka jako sposób prezentacji trésci ewangelizacyjnych; Parszewska A. Językowy obraz świata w religijnych utworach hip-hopowych.

19 Kromě zmíněné Parabible, která byla původně zveřejňována na internetu, a hip hopové tvorby jde např. o cyklus videí Pastoral Brothers, účast představitelů církví různých denominací ve světských, někdy vyloženě zábavných pořadech apod.

20 Také styl religiózní, sakrální, kultový (kultovní, kultický), konfesní, biblický apod.

21 Příspěvek autorky věnovaný náboženskému stylu zaujímá včetně bibliografie v jinak obsáhle, téměř pětisetstránkové práci Przewodnik po stylistyce polskiej pouhých 24 posledních stran. Ze samotného textu navíc plyne, že se i zde zaměňují pojmy náboženský styl a ,język używany przez ludzi w ramach ich zachowania zwanego religijnym." (Makuchowska 1995: 450). 
V souvislosti s tématem náboženský jazyk a náboženský styl by ještě mělo zaznít, že jejich výzkum zahrnuje většinou ucelený náboženský diskurs. Diskurs je ve slovanské odborné literatuře vnímán obecněji a šśřeji než text (srov. NESČ), ale ani v rámci jednotlivých slovanských národních lingvistik a sociálních věd nepanuje naprostá shoda v interpretaci tohoto pojmu. Převažuje názor, že diskurs je jazyková reprezentace určitého výseku mimojazykové skutečnosti, která je jedinečná a pokaždé závislá na jistém společenství (jeho jazyku, kultuře, hodnotách). Tím společenstvím jsou míněny jak sociální makrostruktury typu národ či etnikum, tak daleko menší skupiny vč. rodiny. Tato jazyková reprezentace je podmíněna způsobem nazírání lidského života, jazykovým obrazem světa. Jde o verbální i nonverbální formy reflexe skutečnosti, vlastní i cizí skupiny, komunity, která je vnitřně organizována a propojena různými druhy neformálních, formálních až institucionálních vztahů. V rámci analýzy diskurzu se tedy zohledňují nejen samotné texty (přesněji: systémy kódů, v nichž jsou generovány), ale i jejich sociální kontexty (srov. Maingueneau 2006; Haider 2017). Vzhledem k tomu, že sociálními skupinami mohou být konfesní komunity, jedním z (sub)typů diskurzu je - logicky - náboženský diskurz. Ten se stejně jako každý jiný řídí určitými normami, které jsou uplatňovány skrze konkrétní komunikační strategie typické pro sféru sacrum. Analýzu náboženského jazyka ukotvenou v popisu náboženského diskurzu preferuje i zmíněný David Crystal (2018).

\section{2 / PRÁCE S JAZYKOVÝM MATERIÁLEM}

V tomto oddíle př́spěvku se věnujeme konkrétnímu jazykovému materiálu. K analýze poslouží tři soudobé tituly tištěných médií pro (především) katolické děti a mládeži. Naším záměrem je posoudit, jaký je jazyk sacrum, který má oslovit nejmladší generaci věřících. ${ }^{22}$ Proto jsme zvolily tři do značné míry nehomogenní předlohy. Jedná se o časopis Tarsicius (časopis pro kluky u oltáře) určený ministrujícím chlapcům, časopis In! (divč̌ svět) pro dospívající dívky a časopis Nezbeda (zábavný křest'anský měsičník pro děti) pro mladší děti bez rozdílu pohlaví. V prezentaci se o těchto časopisech zmiňujeme právě v tomto pořadí - začínáme časopisem čtenářsky nejnáročnějším, končíme vyloženě dětským periodikem. Pokaždé se jedná o dubnové vydáníi ${ }^{23}$ uvedených měsíčníků, a to s ohledem na aktuálnost tématu Velikonoc a předpokládanou větší míru spirituality, než je tomu v jiných číslech periodika. Vzhledem k omezenému rozsahu textů rezignujeme na kvantitativní vyhodnocení výsledků a soustředíme se spíše na komentovanou prezentaci.

\section{1 / Charakteristika analyzovaných čísel časopisů a nástin jejich obsahů}

Použití antroponyma v názvu časopisu Tarsicius je symbolické. Sv. Tarcisius byl římský chlapec z doby pronásledování křestanů ve 3. stol., který položil život, aby potřebným přinesl eucharistii. Název časopisu tak zřejmě odkazuje na toho, kdo má být pro ministranty vzorem.

22 U slova „věřící dlužno podotknout, že implementace víry a její hloubka je v této věkové kategorii jaksi předem daná a je úměrná míře prožívání duchovna v konkrétní katolické rodině, v které mladý člověk vyrůstá a v které vlivem výchovy uvěřil, že křestanská interpretace světa je pravdivá, „,zal na vědomí existenci Boha nebo jiných nadpřirozených bytostí, obrací se k nim s prosbami a s rituály, jež mu byly doporučeny a kterým přivykl, př́ipadně si je oblíbil“ (Říčan 2002: 246).

23 Všechna tři dubnová čísla jsou z roku 2020; v případě časopisu Tarsicius jde o 20. ročník v pořadí, In! 16. a Nezbeda - 29. ročník. Rozsah časopisů se pohybuje mezi 20 až 30 stranami. 
Symbolický charakter má pravděpodobně i plamínek místo tečky nad oběma -i-v názvu (Tarsicius) - mohlo by jít o symbol Ducha svatého.

Časopis má výrazně duchovní rozměr a je určen ministrantům, tedy chlapcům patř́íím alespoň zčasti do sféry sacrum, překračujícím její pomyslnou hranici. Ačkoli ne všechna témata, jimž se periodikum věnuje, jsou náboženská (viz články Hollywoodská rodina, Zajimavosti ze světa nebo Už mě to vážně nebavíi ${ }^{24}$ ), duchovní problematika převažuje. Autory textů jsou často muži $\mathrm{s}$ různým stupněm svěcení (jáhen, kněz, biskup). Texty jsou doplňovány záběry z bohoslužeb, kněžského semináře, akcí pro kněze nebo jednoduše fotografiemi mládeže. Časopis využívá také žánr komiksu, který bývá mezi chlapci oblíben.

Nejdřive představíme obsah časopisů, nebot i na základě pouhého přehledu tematického zaměření textů a jejich názvů (titulků) si lze vytvořit určitou představu o použitých jazykových prostředcích. Na obalu je teenager na kole, v přírodě, v prřslušném sportovním „outfitu“, což je pro chlapce v určitém věku přitažlivé spojení. Nejdřiv (s. 2) promlouvá $\mathrm{k}$ ministrantům arcibiskup Otčenášek s cílem povzbudit je $\mathrm{k}$ bohulibé službě - $\mathrm{k}$ ministrování, následuje zamyšlení nad pravidly a autoritou církve. Další strana přináší článek nazvaný Jak prijimout Krista, když nemüžu na mši? věnovaný tzv. duchovnímu přijímání. Dvojstrana $4-5$ je určena rozhovoru $\mathrm{s}$ rodinou, která natáčí videa na youtube. Interview má atraktivní titulek Hollywoodská rodina a postrádá duchovní přesah, je však pro náctileté bezesporu zajímavé. Následující dvojstranu zaplňuje kreslený komiks Válečník Ignus s dobrodružným motivem boje proti symbolu zla Dáblově krvi. Strana 8 nabízí hry s velikonoční tematikou, odlehčený je i obsah na s. 9, kde kromě úvahy faráře Košuliče o fenoménu předsevzetí nacházíme vtipy a úkoly $\mathrm{k}$ luštění. Další zamyšlení, tentokrát nazvané Je PRAVDA jenom jedna?, a př́běh Uzdravení v náruči, který je aluzí na Ježíšovy uzdravující schopnosti, obsahuje následující stránka. Strana 11 pak přináší zajímavou paralelu - přirovnává se vyváženost $\mathrm{v}$ doslovném (fyzickém) a přeneseném významu: Naplňování postních prèdsevzetí je nèkdy docela podobné chỉzi po napnutém laně. Stač malé zaváhání a clověk letí. Ačkoli se zpracování tématu patrně chlapcům jeví jako atraktivní, protože přináší zajímavostí ze světa, zůstává otázkou, zda je opravdu vede např. ke zpytování svědomí. Následuje vzdělávací stránka o ministrování během Velikonoc, která mladé čtenáře poučuje o tom, co se děje při katolických bohoslužbách během největších svátků a o symbolice dané liturgie. Jelikož chlapce často baví sport, lze usuzovat, že pro ně bude přitažlivá reportáž z futsalového mistrovství Evropy Kněži v ZÁPALU (s. 13). Celé další čtyři strany jsou věnovány fotografickému komiksu s hrdiny z řad teenagerů na téma Kdo je věrný v malém; učí chlapce nešidit maličkosti, ale žít a dělat vše poctivě. Fiktivní rozhovor s psycholožkou na téma (aktuální) koronavirové karantény, nazvaný Už mě to vážně nebaví!, přináší s. 18. Následuje reportáž z kněžského semináře Nepomucenum v Římě a také na s. 20 zůstává čtenář v zahraničí, protože se dozvídá o propasti (foibe), která je jedním ze symbolů pronásledování ŕímskokatolické církve komunistickým režimem, a o knězi-mučedníkovi. Pokračuje se historickým okénkem Byla poslední večěre velikonoční? a zamyšlením nad modlitbami Zeleného čtvrtka. Na řadu přichází další komiks, Nejsilnějšš zbran̆, tentokrát s ryze duchovním tématem o mučednické smrti P. Emila Kapouna. Na zadním přebalu vidíme zajímavosti ze světa automobilů, které s ministrováním sice nesouvisejí, ale jsou pro čtenáře časopisu jistě nepřehlédnutelným lákadlem.

Veškeré citace $\mathrm{z}$ předlohy uvádíme $\mathrm{v}$ tomto př́spěvku v kurzívě a bez úprav. 
Rádoby moderní název druhého časopisu (In!) tak trochu svádí a naznačuje, či dokonce slibuje, že jeho čtenářky budou mít přehled o dění v komunitě věříí mládeže, případně budou mít status moderních dívek. Anglicismus in (být „in“) patří k oblíbeným slovům mladé generace. Autory textů by měly být dívky, v jednom případě katolický kněz. Na zadním přebalu periodika je napsáno, že je určeno děvčatům ve složité době dospívání, s čímž koresponduje také jeho podnázev (dívči svět). Grafická úprava měsičníku je podle nás adekvátní cílové skupině; v oblibě jsou květiny a motýli, poněkud infantilní obrázky lamy (s. 7) nebo smyšlené postavičky Chyby (s. 18), celková barevnost. Dủležitou ikonickou složkou jsou fotografie dívek adekvátního věku (viz přebal a různé stránky), popř. skupin mládeže. Názvy rubrik jsou voleny tak, aby ladily s názvem časopisu (srov. INterview, INkognito), někdy i za cenu toho, že se obsah rubriky s jejím titulkem rozchází (rubrika INkognito obsahuje text, jenž významu „utajený“ č̃i „nazapřenou“ neodpovídá). Na konci názvu článku (rubriky) je většinou vykřričník, patrně umístěný paralelně k názvu časopisu (In!), nikoli např. z důvodu naléhavosti sdělení. Ne vždy mají texty v časopisu náboženský charakter, viz např. komiks (s. 11-14), rozhovor (s. 4-5), výzva ke zřeknutí se smartphonu na jeden den (s. 7). Vždy ale usilují o prezentování křestanských nebo obecně lidských hodnot.

Vrátíme-li se k obsahu textů, zjištujeme, že úvodník Přítomnost (s. 2) je úvaha, obsahující myšlenku, že je zbytečné řešit minulost i budoucnost, protože ty nám - na rozdíl od přitomnosti - nepatří. Následuje citát sv. Alžběty od Nejsvětější Trojice: Bưh nás miluje až do té míry, že v nás přebývá, stává se nám druhem v naší samotě, důvěrníkem a přitelem v každé chvíli. Citát s ústřední myšlenkou koresponduje snad jen v tom smyslu, že Bůh je v nás přítomen vždy. Strana 3 patř́i rubrice Aktuálně, která v tomto př́padě hledá odpověd' na otázku z titulku Je to pravda, nebo ne? Rubrika učí dívky kritickému přístupu k mediálním zprávám; použity jsou termíny hoaxy, fake news, dezinformace a jejich význam je objasněn. Celkově text nemá duchovní rozměr, jen na samém konci se odkazuje na salesiánské mediální centrum, které vede mládež ke kritickému přijímání mediálních obsahů. Další dvojstrana patří rubrice INterview, s titulkem Nejdrsnějši muži -drakobijci. Jde o fiktivní rozhovory s Harrym Potterem, Českým Honzou a Bilbem Pytlíkem na téma láska a osobní úspěchy. Dospívajícím dívkám může text připadat vtipný, na náhodného čtenáře působí spíše povrchním dojmem. Strana 6 je věnována rubrice INkognito a tentokrát přináší článek Řešime VÍRU: Jakje to možné?, který nabízí zamyšlení nad tím, v čem byl Ježiš Bůh a v čem člověk. Na stránce je i krátký text dívky Bojím se jít po dlouhé době ke zpovědi s následným povzbuzením ze strany kněze. Rubrika IN action (s. 7) s článkem NO SMARTPHONE, NO DRAMA: Velká výzva pro tebe! prezentuje sympatickou formou hodnotu sebezáporu, pevné vůle (vydržet den bez mobilního telefonu) a času, jejž lze využít smysluplněji. Následuje text Velikonoce v otázkách a odpovédích (s. 8), a to v rámci rubriky IN müsli, ${ }^{25}$ který vysvětluje některé zvyky, tradice a události spojené s Velikonocemi: odlétání zvonů do Říma, uctívání kř̌̌že, prostrace, př̀idávání soli do svěcené vody, délka setrvání Ježíše v hrobě. Text Chci být jiná! v rámci rubriky INside (s. 9) je př́během o dvou dospívajících dívkách, které nejsou spokojené se svou postavou, ale díky společnému setkání si uvědomí, že každý z nás jednoduše „nějak vypadá“, což je interpretováno jako vůle Boží. Bưh zařídil tohle pěkné setkání, díky kterému ted' (obě) ví, že co je pro jednoho sen, je pro druhého na obtíž, píše se v článku, který téma vzhledu řeší poněkud prvoplánově, ale svou

25 Proč se rubrika jmenuje müsli, nám není známo. Může se jednat o podobnost se slovem „mysli“, tedy „myšlenky“, anebo o vyjádření skutečnosti, že obsahuje drobné postřehy různého druhu, je směsicí krátkých informací. 
cílovou skupinu má patrně šanci oslovit. Rubrika Duchovní INjekce s textem Kristus žije! Opravdu! Zajímavosti ze světa (s. 10) přináší povzbuzení na téma Kristus a mladí (mládí). Na následujících čtyřech stranách je zmíněný fotografický komiks Tady něco nehraje o čtyřech dívkách, které reagují na lež jedné z nich, jež měla zakrýt pravdu, že vyhledala pomoc psychologa. Rozhovory jsou vcelku jazykově i myšlenkově chudé, ale téma významu psychické podpory ze strany vrstevnic je relevantní a text má přesvědčit čtenářky o tom, že ostuda není ani odbornou pomoc vyhledat, ani se k tomuto činu přiznat. Článek Jaro je tu, nebud' pozadu! (s. 15) nabádá dívky k pohybu venku a nabízí tipy na konkrétní aktivity. Následující dvě strany poukazují na relevantnost úspěchu (rubrika IN téma, článek Úspěch, či neúspěch? Tot' otázka!), poté přichází na řadu (s. 18) opět rubrika IN müsli s duchovně ctižádostivějším článkem Neboj se chybovat. Článek Pomoc, mám alergii na lidi (s. 19) je snahou o vtipné návody, jak zacházet s emocemi, což je v případě dospívající mládeže téma vcelku př́hodné. Následuje dvojstrana věnovaná zdravému jídelníčku, který dívky může zaujmout, poté rubrika INtelekt, v jejímž rámci najdeme i soutěž o knihu a pozvánku na SKAM (Setkání Křestanské Aktivní Mládeže). Strana 23 a rubrika IN test nabízí možnost otestovat vlastní znalosti (Otestuj se! Umišs youtubersky?) a mladistvé může zaujmout. Zadní přebal je věnován propagaci nadačního fondu časopisu IN! a knihy Př̌sně tajné!!!, která je podle autorů o chození, lásce a intimních věcech.

Časopis Nezbeda, který nese stylově př́znakový (emočně zabarvený) název, je určen děvčatům i chlapcům a hravě-poučnou formou je seznamuje s křestanstvím. Texty jsou doplněny četnými kreslenými obrázky, méně často fotografiemi, které někdy souvisejí, jindy nesouvisejí s náboženskou tematikou. V časopise se střídají duchovní a neduchovní témata, většinu tvoří ta druhá. Jazyk není adekvátní všem věkovým skupinám dětí, místy možná děti potřebují, aby jim pojmy dovysvětlili rodiče (jáchymovské lágry, duchovní elita národa, okázalé šaty).

Na obalu je asi jedenáctiletá sportovně oblečená dívka, která trhá kopretiny. Dále jsou na něm ve výřezu umístěny dvě menš́ kresby a jedna fotografie: kreslený výjev zachycující Ježiše před Pilátem, obrázek holčičky, která dumá nad svým předsevzetím, a fotografie z cest mladé ženy po Indonésii. V následující rubrice Poznáváme naše světce (s. 3) se děti seznamují se sv. Hedvikou Slezskou. Na další straně je text nadepsaný Hrdinové s velkým srdcem a je o hrdinství malého skauta v době nacismu. Osudy chlapce podle nás nemají explicitně duchovní přesah, působí spiše jako motivace k odvaze. Na tento článek navazuje (s. 5) medailonek o Jiřím Stránském (Jiř́ Stránský), politiku a skautovi, který s předchozím př́během nepř́mo souvisí. Strany 6-7 nabízejí třetí díl př́běhu o sv. Bernadette Soubirous, bohatě doprovázeného obrázky. Strana 8 přináší text nazvaný Moje předsevzetí, který vypovídá o překonání pokušení v postní době a objasňuje pravý smysl postu. Další tři strany spolu souvisejí a obsahují doplňovací cvičení s tajenkou na téma Velikonoční události a kreslený př́běh pašijí (beze slov). Následující trojstrana (s. 12-14) je věnována rozhovoru s mladou cestovatelkou Barborou Hubáčkovou, který je nadepsán jednoduše Do Indonésie za studiem a jehož obsah je prakticky zcela světský kromě části, kde se cestovatelka trochu rozpovídala o životním stylu souvisejícím s islámem. Strana 15 je zpưli věnována plemeni bernského salašnického psa a částečně krátkému kreslenému př́iběhu souvisejícímu s postem (rubrika Otík). Kluci z agentury DAH (s. 16-17) je dobrodružný seriál, v jehož záhlaví je umístěno motto ze starozákonní knihy Př́sloví: Neprávem nabyté poklady neprospějí. Následující dvojstrana přináší př́běh o vlaštovce a vzdělávací okénko o kapustňákovi. Díl ze seriálu Cesty Old Shatterhanda (s. 20-21) zprostředkovává dětem dobrodružství z Divokého západu, a to bez 
dalších, hlubších obsahů. Př́běh Malé kuřátko (s. 22-23) ukazuje dětem hodnotu pomoci; navazuje návod na výrobu ozdobného količcku s motivem kuřátka. Následná dvojstrana o Kruhové čítárně Britského muzea má informační (vzdělávací) charakter. Další stránka (s. 26) je hravá a učí malé čtenáře postřehu a přemýšlení. Na s. 27 jsou umístěny dětské vtipy a na zadním obalu komiks Kamarádi.

\section{2 / Základní témata (motivy) a křestanské hodnoty vyjádřené pro- střednictvím časopisů}

Kdybychom měly shrnout základní motivy posuzovaného čísla časopisu Tarsicius, byly by to jistě tyto:

I Poslušnost vs. svoboda: V poslušnosti Církvi pak najdeš i ty jako jednotlivec pravou svobodu [...]; [...] výmysl a nařizení Církve, usurpace moci, rouhání a pýcha, to by bylo proti naší svobodě [...], Bůh vytvářní pravidel svěril člověku.

I Vůle/vytrvalost vs. pohodlí: Předsevzetí může být cokoliv, kdy se rozhodnu si něco odříct nebo se rozhodnu něco udělat [...], něco nepřriemného [...]. Abych dokázal sám sobě, že nejsem závislý? Anebo abych ukázal druhým? Ne, to bychom nepochopili pưst. [...] abychom objevili velikost jeho lásky. To, že on se dokázal zřici sám sebe kvioli nám a pro nás.; Nepohodlí a překonávání překážek připravuje člověka na vytvoření a udržení vlastní pohody.; (v souvislosti se sportem) Jsem moc rád, že vám kněži mohou být př́kladem také ve sportu a s tím spojenou pílí a také odhodláním pracovat na sobě.

/ Empatie: potěšit a povzbudit.

I Boží láska: Ježǐš na kř̌̌ži má rozpjaté ruce a objímá takto celý svět, všechny lidi [...]. Rozběhněme se za Ježíšem, aby nás objal a my se v jeho náruči uzdravili. Ježiš za nás zemřel, aby nás vykoupil, spasil a my jsme jednou došli do nebe.

I Nezištná služba: [...] slovo ministrant znamená přisluhovat, sloužit [...] s velkou láskou, až do konce svých sil, do poslední kapky krve [...]. Kristus sloužil dobrovolně [...]. Vaše služba by měla být obětavá, nezištná, svědomitá a kvalitní. Doufám, že se nikdo z vás neptá „A co za to?“ [...] S jakou úctou a láskou mu posloužila P. Maria, když to někdy od ní potřeboval?; (letos o Velikonocích) nebudeme mít možnost ministrovat.; Máme tu čest být blízko!

I Příprava na kněžství: Seminář je hlavně o každodenní snaze jít spát jako o něco lepší člověk než včera a jako člověk, kterýje o něco bližz našemu Pánu než včera [...] jako bohoslovci na sobě pracujeme.

I Autorita církve: [...] církevní nařízení zavazuje pod hříchem [...]. Je Církev dobrovolné sdružení hledačů a následovníků Krista, nebo je Bohem chtěná, milujicí Matka a strážkyně pokladů víry jí svěrených, která má záruku, že to, co koná, i když lidsky, má ručení Boži (... a brány pekelné ji nepřemohou)? Má-li záruku neomylnosti, kterou jí dává Ježíš Kristus, její hlava, potom má i právo a moc rozhodovat.

I Svaté přijímání (jako nejintimnější kontakt s Bohem): [...] veucharistii nepřijímáme něco, nýbrž Někoho - sám Pán, Ježiš Kristus ukřižovaný a zmrtvýchvstalý. On je živý! V př́ípadě nemožnosti přijmout eucharistii se nabízí alespoň duchovní přijímání: Díky Bohu nemusíme ztrácet hluboké spojení s naším Pánem. Může k nám přicházet v duchovním svatém přijímání.

I Mravní čistota: Nezapomínej, že jsi opravdu chrám Boží.

I Pravda: [...] nějaká základní mravní norma, která by platila pro všechny lidi bez rozdílu [...]. ANO, existuje jedna pravda [...]. Tato myšlenka není doložena jen evangeliem [...], ale celou filozofickou 
tradicí, která se odvolává na Sokrata [...], pravda je neměnná, a proto za ni stojí i zemřít.

I Vděčnost: Je krásné umět děkovat. Je krásné umět chválit. A je krásné umět ve všem, co prijímáme jako každodenní maličkost [...], hledat a nacházet odlesk Boží slávy [...].

I Odpuštění: Pokud nedokážeme odpustit, zř̌́káme se vlastní víry.

I Zlo v podobě komunismu: [...] komunistický teror [...], trnem v oku jim byla katolická církev [...], došlo k vraždám kněží, seminaristů i ostatních věřicích lidí [...]; blahoslavený kněz [...] byl zavražděn komunistickými partyzány [...], P. Francesco Bonifacio [...], kněz, který pevně hájil víru proti komunistické zášti (vzor kněze hodného následování).

Jak bylo uvedeno výše, časopis In! se snaží nenásilnou formou vštěpovat dospívajícím dívkám katolické/křestanské hodnoty, upozorňovat na duchovní i obecně lidské kvality. Uved'me některé $\mathrm{z}$ nich:

I Víra ve zmrtvýchvstání: [...] jeho (Ježíšova) božská moc způsobila, že třetí den po své smrti vstal z mrtvých. Tato událost je maximou křest'anské víry a di̊kazem jeho božství.

I Víra v Boží lásku: Velikonoce jsou největší křest'anské svátky [...], Bưh tak miloval svět, že dal svého jednorozeného Syna, aby žádný, kdo v něho věří, nezahynul, ale měl věčnýživot [...]. Pán Ježíš tě má rád a pritahuje tě k sobě [...]. Je plný lásky [...].

I Odmítavý postoj k pověrám: Jediné náboženské tradice, které jsou závazné pro křest'any, jsou ty spojené se slavením bohoslužeb [...]. Některé zvyky patři spíše mezi pověry [...], proto je rozumný člověk nedodržuje.

I Přímá relace s Bohem: Bưh má ke každému clověku osobní přistup [...]. Bưh mě miluje - a to se mě týká velmi osobně a konkrétně [...]. Kristus nás zachránil a neustále zachraňuje. On není jen abstraktní Spasitel [...], on je můj Spasitel.

I Vděčnost (za dar života): Kristus žije a chce, abys žil! [...] Kristus žije. On je naše naděje a nejkrásněǰ̌i mládí tohoto světa. Všechno, čeho se dotkne, omládne, stává se novým, naplňuje se životem.

I Sebepřijetí (jako akceptace Božího plánu se mnou): Sebeprijetí je dưležité [...], ale není to rezignace [...]. Tělo jsme dostaly do péče od Boha.

I Sebereflexe: Ideální prevencí (chyby) je večerní zpytování svědomí. Uvědomit si, odevzdat Bohu, pomodlit se za sílu to řě̌it, odhodlání věci změnit.

I Hodnota člověka: Máš právě takovou cenu, jakou mášv Božích očích (sv. František z Assisi).

I Uvědomění si relativity úspěchu: Copak ze mě dělá dobrého člověka? Kolik mám medailí, nebo spíš to, že se snažím být laskavá, zachovat si ve všech situacích optimismus, dělat druhým radost a sama se radovat z maličkostí? [...] Jednička z testu díky taháku, nebo poctivá př́prava na test, který se mi nakonec na jedničku nepovede? [...] Máme sny a cíle správně nastaveny?

/ Využívání každého dne naplno: [...] tento dnešní den, tato chvíle [...] je pozváním, výzvou, Božím darem. Když ho nevyužijeme, aniž bychom ho nějak vnímali a aspoň malinko proměnili [...], tak se už dalš́ den stane zase jenom minulostí.

/ Pevná vưle a zmíněné moudré využití času (viz text o zřeknutí se mobilního telefonu na jeden den).

Také časopis Nezbeda seznamuje děti prostou formou s křestanskými hodnotami. Vzhledem $\mathrm{k}$ různému věkovému složení čtenářů přináší, jednoduše řečeno, pro každého něco, o čemž svědčí následující různorodost rozváděných témat: 
I Poslušnost: [...] poslechnout rodiče znamená poslechnout Boha.

I Relace s Bohem: [...] vztah k Bohu, záliba číst Písmo svaté a účastnit se bohoslužeb [...], práci i povinnost nedělají (řeholnice) jen z poslušnosti, ale predevšim z lásky $k$ Bohu.

I Oslava Boha: Hosanna na výsostech!

I Duchovní boj: předsevzetí [...], (boj proti) pokušení [...]. Doba postu není něco, co by mě mèlo trápit.

I Vytrvalost, důslednost: V modlitbě jsem prosila, abych vytrvala $v$ tom, co jsem si slíbila.

I Odvaha: Nebojím se [...] skaut rozhodně neztrácí odvahu.

I Pokora: Malá trápení jsem prijiala potichu a s pokorou.

I Služba druhým: Odkaz Jiř́ho Stránského: Když můžěš udělat radost, tak musíš!

I Řeholní život: [...] posláním řehole je Boží chvála, naučit se rozjímat, dodržovat klášterní pravidla a predpisy.

I Zlo v podobě komunismu: Vjáchymovských lágrech byla zavřena duchovní elita národa.

\section{3 / Modelování obrazu sacrum prostřednictvím jazyka}

„Jazyk je strukturou, která nás permanentně obklopuje a která opanuje náš způsob myšlení. Myslíme v určitých strukturách, které nám náš jazyk umožňuje [...]," píše religionista David Václavík. Jazyk nás také omezuje a důkazem je fakt, že „některé pocity, emoce, které máme, neumíme přesně pojmenovat, vystihnout určitým slovem, které nám jazyk nabízí. Pak jsme zmateni a neumíme se v nastalé situaci zorientovat"(Václavík 2010: 22). Není pochyb, že se v tom, co tvoří nejniternější podstatu našeho bytí a co nás zároveň přesahuje, orientovat chceme. Vážíme slova a těch, na která jsme si zvykli, se nechceme vzdát. Stejně tak silný vliv na nás mají slova, která slyšíme (čteme) poprvé. Dětský př́iemce náboženské literatury, byt více populární než odborné, je mnohdy poprvé konfrontován s (tištěným) textem spirituální povahy, jehož produktorem není osoba z nejbližšího okolí, na jejíž projev je zvyklý. Proto nyní zaměříme pozornost na konkrétní úseky textů obsažených v posuzovaných časopisech, abychom zjistily, jaké jsou jednotky jejich výstavby. Již zběžná reflexe narativu, který používá redakce (spoluautoři) časopisů, odhaluje př́itomnost lexika „vyššího“ (vznešeného, slavnostního, oslavného), poněkud archaického (např. biblický frazeologismus brány pekelné, morfologický archaismus Zmrtvýchvstání Páně nebo tělo a krev Páně, konstrukce zavazovat pod hříchem či lexikální historismus setník), přitomnost jisté míry patosu a nadsázky (až do konce svých sil, do poslední kapky krve, nejkrásnější mládí tohoto světa). Dále nacházíme četná metaforická pojmenování a perifráze (církev je milující Matka a strážkyně pokladů víry, duchovní elita), ozdobná epiteta, častěji v inverzním postavení vzhledem $\mathrm{k}$ rozvíjenému slovu, než je tomu v běžném či odborném vyjadřování (kromě tradičních slovních spojení Písmo svaté, mše svatá, Matka Boží aj. je to např. svátost oltářní), parémiologické prvky (Svatý za týden - svatý na týden), deminutiva (kuřátko), ale i terminologii (teologické/latinské i světské), anglicismy a internacionalismy (no smartphone, no drama, müsli, usurpace, rezignace), prostředky stylu prostě sdělného (otestuj se, youtubersky, chození, intimní věci, tahák, tady něco nehraje), pojmy z oblasti etnografie a folkloru (velikonoční klepačky). Na tomto místě jsme uvedly pouze některé př́klady ilustrující jazyk časopisů, mnohem více jich nabízíme níže.

O Bohu se v časopise Tarsicius píše jednoduše, ale uctivě jako o Pánu Bohu, přičemž první božská osoba je označována jako Otec, druhá jako Ježíš / Kristus / Kristus Pán / Ježǐš Kristus 
ukřižovaný a zmrtvýchvstalý / Vzkř̌̌šený Pán / Zmrtvýchvstalý Kristus (poslední tři označení souvisí s velikonoční tematikou), třetí jako Duch svatý. V souvislosti s osobami vyznávajícími víru v Krista se uvádí bud' označení věrící, nebo Boží děti, anebo se používá opisné vyjádření pokřtěný clověk. Celé společenství věříích je pojmenováno slovem Církev / církev, přičemž se tím míní církev katolická. Zasvěcení služebníci Boží v církvi jsou v analyzovaných periodikách kněží a řeholnice, osoby nezasvěcené jsou katoličtí laici. Z představitelů církve byli uvedeni biskup Otčenášek a Svatý Otec / papež, resp. jmenovitě dřívější papež Benedikt XVI. Muži, kteří se na povolání kněze připravují, jsou autory textů časopisů nazýváni bohoslovci / seminaristy / zájemci o kněžství. Kněžství je pak prezentováno jako něco velmi cenného a výjimečného. Ministrantům se dává za vzor mimo jiné chlapec, který se na kněžství pripravoval, Roland Rivi. Zmíněny jsou i osoby světců, konkrétně P. Maria, dále Petr (myšleno sv. Petr, jeden z apoštolů), blahoslavený José M. Escriva nebo sv. Hippolyt Řimský. Nejbližší Ježíšovi spolupracovníci jsou apoštolové. Řeč je i o postavě, jež byla zodpovědná za Kristovo ukřižování, Pilátovi.

V časopise In! se v souvislosti s osobní reprezentací transcendentna používá slovo Bưh / Pán / Hospodin (starozákonní výraz). Dále je Bůh obsažen v nadřazeném pojmu Nejsvětějšš Trojice, přičemž první osobou trojjediného Boha je Otec, druhou je Ježišs / Boži Syn / Pán Ježǐs / druhá božská osoba / pravý člověk a pravý Bůh, což je rozvinuto formulací v něm je spojen Bưh a člověk, a dále čteme, že ačkoli je (Ježiš) rovný Bohu, ponižil se a v poslušnosti nebeskému Otci přijal úděl člověka se vším všudy [...] (kromě hříchu), má tedy lidskou duši i tělo. Dále se o Ježíšovi píše: Ovšem jako druhá božská osoba zůstal neoddělitelně spojený s Otcem a Duchem svatým v Nejsvětější Trojici [...] Je v něm spojen Bưh a člověk. Ježíš-člověk je také charakterizován takto: Potřeboval jíst, byl unavený, radoval se [...]. Ježǐs nevyhledával senzace. Nekonečně veliký Bưh žil zcela skromněa obyčejně [...], poslouchal vưli Otce s trpělivostí a tichostí. Třetí osobou je Duch svatý. V In! je zmíněno i několik světců, kteří hrají v katolické víře významnou roli př́mluvců a pomocníků lidí na cestě k Bohu: sv. Pavel (prezentován jako ten, kdo žasne nad pokornou láskou Pána Ježǐše), sv. Alžběta, Matka Tereza nebo sv. František z Assisi. Pro společenství Kristových následovníků, tedy církev, je použito označení Boží lid / křest'ané / církev s otevřenými dveřmi [...], popř. všichni / každý člověk / oni (srov.: Musíme vytvořit prostor všem a každému s jejich pochybnostmi, traumaty, problémy a hledáním identity, s jejich omyly, př́běhy, zkušenostmi s hříchem a se všemi jejich nesnázemi). Dílčí křestanské skupiny (např. čtenáři posuzovaných časopisů a jejich vrstevníci) jsou nazýváni parta ze spolča / spolčo ${ }^{26}$ / parta / skupina / ostatní mladí, resp. - v rámci ekumeny - také mládežz z různých křestáanských církví. Hlavou církve je Svatý otec I Svatý otec František, jejím zástupcem v lokálním měřítku je kněz.

V dětském křestanském časopisu (Nezbeda) se o personifikovaném, figurativním božství píše jednoduše jako o Bohu, druhá Božská osoba je nazývána Pán Ježišs / Ježíš / Mistr / Syn Boží / Mesiáš / syn Mariin. Na rozdíl od předchozích dvou časopisů a od zmíněného výrazu Mesiáš zde složitější obrazná pojmenování nenajdeme. Ze světců se uvádí Ježíšova matka: Pana Maria nebo „krásná Paní“. ${ }^{27}$ Dále je zmíněna sv. Hedvika Slezská, sv. Jan Pavel II., (apoštol) Šimon Petr, všichni čtyři evangelisté a Marie Magdalská. Děti jsou seznamovány i s osobami spjatými s velikonočním příběhem: s Jidášem, Pilátem, Šimonem z Kyrény (který pomáhal Ježǐšovi nést kř̌ž na Golgotu), 
postavami setníka, velekněze, zločince. Co se týče dalších osob, jsou zmíněny benediktinky, ${ }^{28}$ jsou použita slova sestry a bratři (jako oslovení křestanů), křest'anské společenství, křestanka.

V Tarsiciovi jsme narazily i na nevšední výraz malověrní, který se objevuje v původním významu ,lidé malé víry', ale kontext svědčí o tom, že jeho použití bylo motivováno snahou povzbudit př́jemce $\mathrm{k}$ silnější víře, nikoli ho kritizovat, odsoudit. Čtenáři časopisu jsou zde oslovováni výrazy: ministranti / drazí ministranti / přátelé v ministrantské službě / kluci ministranti / skoro velikonoční ministranti, anebo se o nich píše ve třetí osobě jako o společenství ministrantĩ.

Z pojmenování sakrálních objektů obsažených v dubnovém čísle Tarsicia uved'me slova kostel, resp. katedrála, ${ }^{29}$ názvy konkrétních chrámů: Svatovítská katedrála, chrám sv. Ludmily v Praze, Loreta nebo bazilika sv. Petra. V souvislosti s přípravou budoucích kněží je zmíněna Papežská kolej Nepomucenum v Řimě. Bible je pojmenována jako biblický text / Písmo svaté, popř. byl použit název její části - Janovo evangelium. Dále se píše o množství svitků s biblickými a jinými texty u Kumránu. K církevní organizaci se vztahují slova diecéze $e^{30}$ a farnost.

V časopisu In! jsou zmíněny objekty souvisejí s výkonem kněžského povolání, praktikováním víry apod., jakož i abstraktní pojmy spojené s křestanskou (katolickou) vírou. $\mathrm{K}$ těm prvním patří Bible a její části: Nový zákon i Starý zákon a evangelia, dále misál ${ }^{31}$ nebo zvony. V této souvislosti jsou zmíněna konkrétní unika: zvon Zikmund z pražské katedrály sv. Víta a zvon Marie $z$ kostela Matky Boží před Týnem. Důležitými symboly víry jsou bezesporu kř̌ž, svěcená voda - zde jsou uvedeny v př́mém významu, stejně jako sưl v kontextu Požehnaná sưl je svátostina [...] sůl chrání čistotu a ochraňuje pred zkázou. K použitým pojmům označujícím rituály (svátosti) patří biřmování (známé jako svátost křestanské dospělosti) a zpověd' / svátost smírení.

Časopis Nezbeda seznamuje malé čtenáře s konkrétním sakrálním místem, když popisuje skromné prostředí kláštera, kde se místo okázalých šatů nosila pokora a skromnost, nebo s existencí liturgických rouch, Písma svatého, požehnaných svící, čtyř evangelií a křiže. Z pojmenování nehmotných entit jmenujme mši sv. , promluvu (kázání, homilii), růženec (modlitbu), duši, pokušení nebo ráj / království. I tento časopis aktuálně připomíná dětem Popeleční středu, postní dobu, Velikonoce a v neposlední řadě fakt umučení a vzkřišsení Ježišse Krista. Zajímavě časopis prezentuje dětem zjevení Panny Marie svaté Bernadettě: Bernadetta poklekla a začala se modlit. Po chvíli upadla do vytržení. Její tvář pokaždé zkrásněla a všichni $v$ ten okamžik měli pocit čehosi krásného. Nezastírá tedy nadpřirozenou podstatu zjevení, která je podmíněna lidskou pokorou a kterou doprovází nadpozemská krása.

V návaznosti na velikonoční období se $\mathrm{v}$ jednom z časopisů (konkrétně v dubnovém čísle Tarsicia) píše o velikonoční liturgii, která je jiná než běžně, a o oděvu kněze, který s ní souvisí:červený ornát / zelený ornát / bílý ornát, ${ }^{32}$ dále o předmětech jako boční oltár̆, ratolesti, ${ }^{33}$ klepačky $^{34}$ a svíce. ${ }^{35}$

28 Benediktinské kláštery byly dřive běžnými místy pro výchovu dívek z vyšších společenských vrstev.

29 Chrám při sídle biskupa.

30 Církevní správní jednotka v čele s biskupem.

31 Mešní kniha.

32 Barva kněžského roucha symbolizuje např. mučednictví, naději nebo oslavu; je pro daný den předepsána.

33 Ve významu palmových/olivových větví, jimiž lidé vítali Ježíše při jeho slavném vjezdu do Jeruzaléma.

34 Slouží během velikonočního tridua jako náhrada zvonů.

35 Symbol Kristova světla a konce temnoty. 
Z ostatního pojmosloví vztahujícího se ke spiritualitě vzpomeňme ustálené víceslovné spojení viditelné znamení neviditelného Božího pưsobení, několikrát zmiňovanou eucharistii také ve verzích svaté prijímání / tělo a krev Páně / Nejsvětěǰ̌ś svátost / svátost - zpusob chleba a vína / svátost oltářní. V časopise se pochopitelně objevuje doba postní a Velikonoce, které se ve shodě s židovskou tradicí a samotnou Biblí nazývá opisně svátky nekvašeného chleba. Píše se o Svatém neboli Pašijovém týdnu, Květné neděli, Zeleném čtvrtku, Velkém pátku, Slavnosti Zmrtvýchvstání Páně-Velikonoční vigilii. Řeč je také o části mše svaté konané na Zelený čtvrtek, tj. ve čtvrtek Svatého týdne, kterou je missa chrismatis neboli „mše křižma“, či spíše „mše se svěcením olejü“ [...], (kdy dochází k) žehnání oleje pro nemocné, tedy pro svátost nemocných; dále o částech velkopátečních obřadi̊: prostrace, ${ }^{36}$ bohoslužba slova, uctívání křǐže prímluvy, svaté prijímání. Zmíněny jsou i konkrétní modlitby: eucharistická modlitba nebo modlitba děkovná (což je také významem slova „eucharistie“) [...] „děkování nad chlebem a vínem“, modlitba požehnání, děkovné a žehnací modlitby nad chlebem a sýrem [...] i nad olivami [...] Své požehnání dostávalo i ovoce, zvláště pak první, které se urodilo. Pozornost je věnována i abstraktním pojmům: „velikonoční tajemstvi“, tj. ústřední myšlenka veškerého křestanského slavení, ${ }^{37}$ svědomí, naše srdce (ve významu ,místo lidského duchovna ${ }^{38}$ ) a desatero. Symbolické (metaforické) je vyjádření: být u stolu s Kristem Pánem při jeho večeri, také obřad mytí nohou pojmenovávající akt Boží poníženosti a jeho dobrovolné služby člověku; symbolický význam má slovo oheň, rovněž oheň lásky, který znamená Ducha svatého (o letnicích byl seslán na zem v této podobě); světlo je znamením konce pohanské éry a začátku období Kristova vítězství; obnažený oltář (na Zelený čtvrtek) připomíná Kristovu opuštěnost v Getsemanské zahradě, velikonoční beránek symbolizuje Krista aj.

$\mathrm{K}$ tématu Velikonoc $\mathrm{v}$ časopisu In! najdeme kromě klíčového pojmu Velikonoce také velikonoční trídenní, ${ }^{39}$ konkrétně Zelený čtvrtek, Velký pátek a Bílou sobotu, na které navazuje neděle Zmrtvýchvstání Páně. Doba padesáti dnů od Velikonoc se nazývá doba velikonoční. Velikonocům předchází sedmitýdenní postní doba, která začíná Popeleční středou. Časopis se také zmínil o dvou typických velkopátečních obřadech, kterými je prostrace (Na Velký pátek [...] kněz a ministranti [...] si lehají pred oltář a vyjadřují tak absolutní pokoru před Bohem a vděčnost za sebeobětování Krista.) a uctívání křiže (uctívání kř̌̌že je jedna z forem prripomenutí jeho (Kristovy) oběti [...] kdo z nějakého dưvodu nemůže pokleknout, müže kř̌ž uctít alespoň úklonou). Důležitou modlitbou velikonočního tridua je modlitba Sláva na výsostech Bohu, během níž - jak známo - na Zelený čtvrtek odlétají zvony do Říma a na Bílou sobotu se z něho vracejí. Tento zvyk je autorem př́spěvku vysvětlen takto: Mlčení zvonů vyjadřuje velikonoční smutek a mlčení v době utrpení [...] Krista a jeho uložení do hrobu. Zmíněn je oslavný hymnus na Krista, zpívaný o Velikonocích, a typické zvolání aleluja: Aleluja, Chvalte Pána!, který se v postní době v katolické liturgii neobjevuje.

\section{3 / VÝSLEDKY ROZBORU}

Přestože naším cílem není hodnocení analyzovaných časopisů jako takových, sluší se závěrem provést jisté shrnutí výsledků rozboru. Lakonicky řečeno, formálně-jazyková stránka tři

36 Pokleknutí na obě kolena při modlitbě.

37 Smrt a zmrtvýchvstání Ježíše Krista.

38 Takto vysvětluje rozdíl mezí duchovním a duševním např. známý český teolog a psychiatr Max Kašparů: centrem duševna (psyché) je mozek, duchovno (spiritualita) se nachází v srdci (Kašparů 2019: 14). 39 Správně tř́idení/triduum, tj. tři dny následující po sobě. Chybu mohl způsobit program na opravu pravopisu a tato nebyla mechanicky odstraněna. 
křestanských periodik určených pro (nej)mladší čtenáře se výrazně od textové složky jiných časopisů tohoto druhu neliší. Rozhodující je v tomto ohledu spíše duchovní obsah alespoň části publikovaných příspěvků, které se redakce snaží odlehčit zaměřením pozornosti na profánní svět, hry či úkoly sloužící k rozvíjení manuálních zručností. Dále zjištujeme následující fakta:

/ Z textů je patrná (dojisté míry pochopitelná) exkluzivita křestanství, zejména prominentní postavení římskokatolické církve (ostatní denominace se prakticky nezmiňují). Uvádějí se světci uctívaní katolickou církví, Mariin kult je samozřejmostí. Jako stejně bezvýhradně (univerzálně) je prezentována katolická církevní hierarchie a další reálie spojené s její strukturou a fungováním.

/ V motivech panuje pestrost až roztř́šštěnost. S ohledem na různorodost zájmů dětských čtenářů a obtížnost udržet jejich pozornost $u$ daného tématu déle než v rozsahu jedné stránky se však tento princip jeví spíše jako pozitivum než nedostatek.

/ Místy se (možná bezdůvodně) spoléhá na intelektuální vyspělost př́ijemců, zvláště ministrantů. Vychází se - podle nás - z neopodstatněného předpokladu, že použité $\mathrm{v}$ textu pojmosloví je dostatečně srozumitelné (srov. namátkou: svátostina, zášt', totalita, nadpozemský, pokora, živý Ježíš, foibe, seminarista, diecéze, prostrace), popř. se počítá s asistencí rodičů při četbě časopisu. V tomto ohledu jsou nejcennější články vysvětlující prříslušné pojmy, historická fakta, církevní tradice.

I Jazykový obraz sacrum je vytvářen na principu protikladu k profanum, a to prostřednictvím častých opozic typu víra vs. pověra; Boží vs. lidské; práce/vůle/vytrvalost vs. snadné, příjemné; láska/laskavost vs. surovost, lhostejnost aj.

/ Latinismy jsou ojedinělé, daleko četnější jsou anglicismy, a to i tam, kde jejich př́itomnost není nezbytná.

I Celkovou úpravou se časopisy někdy až podbízivě snaží vyhovět vkusu čtenářu (viz komiksové zpracování témat, snaha zaujmout fotografiemi aut, infantilními, romantickými motivy ilustrací.

I Posuzované časopisy sice upozorňují na nástrahy současného světa a varují před bezmeznou důvěrou k sociálním sítím či snahou dospívajících lidí řídit se v životě módními trendy, zároveň nejsou odtrženy od běžného života mimo církev, neomezují se pouze na témata spojená s náboženským prostředím, ale naopak podporují vzdělávání v širokém smyslu slova, poznávání moderních technologií, cizích zemí apod. Tímto naplňují myšlenku, že „žít duchovně znamená žít naplno své lidství, žít prostě jako člověk. Sdílet s ostatními tvory v celku života celý jeho rozmach a sílu a přitom také potvrdit, naplnit a rozvinout biologickou úroveň života tím nejvitálnějším: myslet, poznávat, mít rád a prací dotvářet svět" (Štampach 2000: 22).

\section{PRINTED MEDIA FOR THE CATHOLIC YOUTH THROUGHT THE PRISM OF THEOLINGUISTICS}

SUMMARY In its theoretical part the article is based on the categories of religious discourse, religious style and religious language. Basic terms are explained 
one by one and the authors express their attitudes towards the issue described, referring mostly to works by foreign theolinguists, as this topic has not been researched in the Czech context deeply enough. Subsequently, the authors analyze expressions used in three magazines for (mainly) Catholic children and young readers. Although the language of analysed magazines should meet communication needs of child and adolescent recipients, this is achieved only to a certain extent. God (sacrum) is quite often treated in a manner which is too abstract, as the youngest readers are expected to rely on their parents' assistance while reading. Fortunately, there is a significant number of secular articles without a clearly spiritual dimension in the magazines that broaden their readers' horizons.

\section{LITERATURA}

I Crystal D., 2008, A Dictionary of Linguistics and Phonetics (6th edition), Oxford.

I Crystal D., 2018, Whatever Happened to Theoliguistics? Religion, Language, and the Human Mind, Chilton P., Kopytowska M. (eds.), New York, s. 3-18.

I Flek A., 2018 (2. vyd. 2019), Parabible. Tisková zpráva o našem prezidentovi Ježǐši z Nošovic, Praha.

I Gadomski (Гадомский) А. К., 2017, Теолингвистические исследования в славянском языкознании, Симферополь.

I Haider A. S., 2017, Using Corpus Linguistic Techniques in Critical Discourse Studies: Some Comments on the Combination, Department of Linguistics (University of Canterbury). Dostupné na https://www.researchgate.net/profile/Ahmad_Haider/publication/317045137_Using_ Corpus_Linguistic_Techniques_in_Critical_Discourse_Studies_Some_Comments_on_the Combination/links/5922f405aca27295a8a7b345/Using-Corpus-Linguistic-Techniques-in-Critical-Discourse-Studies-Some-Comments-on-the-Combination.pdf

I Gadomski (Гадомский) А. К. - Končarević (Кончаревић) К., 2012, Теолингвистика, Београд.

I Gadomski (Гадомский) А. К. - Chlebda W. - Čevela (Чевела) O. V. et all. (eds.), 2019, Хрестоматия теолингвистики 2, Ульяновск.

I Łapicz Cz.-Gadomski A. K., 2008, Хрестоматия теолингвистики / Chrestomatia teolingwistyki, Симферополь.

I Grygerková M. (ed.), 2005, Specifika církevní komunikace, Ostrava.

I Grygerková M., 2006, Slang v církevním prostředí, Ostrava.

I Hošek P., 2010, A bohové se vracejí (Proměny náboženství v postmoderní době), Jihlava.

I Hošek P., 2018, Je to náš príběh (teologický esej o vlastenectví a křest'anských hodnotách české kultury), Brno.

I Kašparů M., 2019, Rozhovory pod věží, Brno.

I Končarević (Кончаревић) К., 2015, Pogled u teolinvistiku, Beograd.

I Končarević (Кончаревић) K., 2017, Jezik i religija. Pojmovnik teolingvistike, Beograd.

I Končarević (Кончаревић) K. - Grković-Major (Грковић-Мејџор) J., 2013, Теолингвистичка проучавана словенских језика, Београд.

I Krčmová M., 1997, Persvazivní funkce jako konstituující faktor projevu - funkční styl rétorický. Stylistika současné češtiny, Čechová M., Chloupek J., Krčmová M., Minářová E., Praha, s. 201-209. 
I Kucharska-Dreiß E., 2004, Teolingwistyka - próba popularyzacji terminu. Język religijny dawniej i dziś I, Mikołajczak S., Węcławski T. (eds.), Poznań, s. 23-30.

I Maingueneau D., 2006, Is Discourse Analysis Critical?, „Critical Discourse Studies“, 3(2), s. 229-235.

I Makuchowska M., 1997, Styl religijny. Przewodnik po stylistyce polskiej, Gajda S. (ed.), Opole, s. 449-473.

I Mečkovskaja (Мечковская) Н. Б., 1998, Язык и религия: пособие для студентов гуманитарных вузов, Москва.

I Mlacek J., 2012, Štylistické otázky náboženskej komunikacie (úvahy o jej vymedzovanív štylistickej clenitosti), Ružomberok.

I NESČ: Nový encyklopedický slovník češtiny online, heslo Diskurz. Dostupné na https://www. czechency.org/slovnik/DISKURZ

I Przyczyna W., 1994, Słowo Boże i ludzkie w kazaniu. Charakterystyczne cechy kazania jako utworu mówionego. Wspótczesna polszczyzna mówiona w odmianie opracowanej (oficjalnej), Kurzowa Z., Śliwiński W. (eds.), Kraków, s. 167-170.

I Říčan P., 2002, Psychologie náboženství, Praha.

I Štampach I. O., 2000, A nahoře nic (O možnostech postmoderního človèka žit duchovně), Praha.

I Václavík D., 2010, Náboženství a moderní česká společnost, Praha.

I Zdunkiewicz-Jedynak D., 2004, O Bogu łatwym, lekkim, niewymagającym. Banalizacja języka Kościoła, „Res Publica Nova“, 2, s. 66-71.

I Zdunkiewicz-Jedynak D., 2010, Jak mówić o Bogu językiem współczesnego świata? O dylematach inkulturacji w języku polskiego Kościoła, „Studia Salvatorum Polonica“, 4, s. 87-97. 